\title{
Determination of Rebaudioside A and Stevioside in Leaves of $S$, rebaudiana Bertoni Grown in México by a Validated HPLC Method
}

\author{
Irma Aranda-González ${ }^{1,2}$, Yolanda Moguel-Ordoñez², David Betancur-Ancona ${ }^{3 *}$ \\ ${ }^{1}$ Facultad de Medicina, Universidad Autónoma de Yucatán, Mérida, México \\ ${ }^{2}$ Instituto Nacional de Investigaciones Forestales, Agrícolas y Pecuarias (INIFAP), Campo Experimental \\ Mocochá, Carretera Mérida-Motul, Mocochá, México \\ ${ }^{3}$ Facultad de Ingeniería Química, Universidad Autónoma de Yucatán, Mérida, México \\ Email: "bancona@uady.mx
}

Received 8 September 2015; accepted 18 October 2015; published 21 October 2015

Copyright (C) 2015 by authors and Scientific Research Publishing Inc.

This work is licensed under the Creative Commons Attribution International License (CC BY).

http://creativecommons.org/licenses/by/4.0/

c) (i) Open Access

\section{Abstract}

Stevia rebaudiana is a plant with high sweetening capacity due to its content of glycosides, mainly stevioside and rebaudioside $A$. Several techniques have been used to determine the concentrations of glycosides in Stevia, although an HPLC method is recommended by the FAO/WHO-JECFA. Varieties of Stevia have been recently grown in Mexico, with no previous report of glycosides by a validated method. The aim of this study was to validate an isocratic HPLC method for content determination of main glycosides in the leaves of Stevia cultivated in Mexico. HPLC method was performed using a $C 18$ column $(250 \mathrm{~mm} \times 4.6 \mathrm{~mm}, 5 \mu \mathrm{m})$ and $U V$ detector set at $210 \mathrm{~nm}$. The mobile phase consisted of 32:68 (v/v) mixture of acetonitrile and sodium-phosphate buffer $(10 \mathrm{mmol} / \mathrm{L}$, pH 2.6), set to a flow rate of $1.0 \mathrm{~mL} / \mathrm{min}$. Rebaudioside $A$ and stevioside were determined in two Stevia varieties: Morita II and Criolla, and also validation parameters were calculated. Rebaudioside $A$ content $(\mathrm{g} / 100 \mathrm{~g})$ in Morita II was $15.15 \pm 0.02$ while stevioside was $3.97 \pm 0.003$; in the case of Criolla they were $4.03 \pm 0.01$ and $8.80 \pm 0.14$, respectively $(p<0.001)$. The recoveries of fortified samples were $100 \% \pm 10 \%$ and precision RSD was $\leq 6.27 \%$. The criteria of validation showed accuracy, linearity $(\geq 0.99)$, and precision; therefore, the determination of glycosides was performed with reliability.

\section{Keywords}

Stevia rebaudiana, Rebaudioside A, Stevioside, HPLC, Validation

\footnotetext{
${ }^{*}$ Corresponding author.
} 


\section{Introduction}

Stevia is a genus of plants native to subtropical and tropical regions of South and Central America. Among the 407 species, Stevia rebaudiana Bertoni has the highest sweetness potential due to its high content of diterpene glycosides named stevioside, rebaudioside A, C, D, and dulcoside A. These compounds are steviol glycosides, which are formed by replacing the carboxyl hydrogen atom with glucose, xylose and rhamnose [1]. In generally cultivated varieties, the main steviol glycosides are stevioside, rebaudioside $\mathrm{A}$, rebaudioside $\mathrm{C}$ and dulcoside $\mathrm{A}$ [2]-[4]; among them rebaudioside A and stevioside are the ones in greater quantities. Stevioside is 250 - 300 times sweeter than sucrose but with a bitter aftertaste, while rebaudioside A is 350 - 450 times sweeter than sucrose without aftertaste [2].

The variety of Stevia, weather conditions and farming are factors that contribute to the amount and type of glycosides in the plant. For example, there is one variety of Stevia with low amounts of rebaudioside A and rebaudioside $\mathrm{C}$, while in another variety the main component is rebaudioside $\mathrm{C}$ [5]. Moreover, even the same variety can have higher content of glycosides if it is exposed to high solar radiation or grown with specific crop density (12.5 and 25 plants per square meter) [6]. This has resulted in international reports of stevioside content as low as $4 \%$ [3] or as high as $22 \%$ [4], whereas in the case of rebaudioside $\mathrm{A}$ it has been reported from $2 \%$ [3] to 54\% [4] content in dry leaves of S. rebaudiana; however, considering the total content of glycosides, stevioside and rebaudioside A could represent $9.2 \%$ and $61.6 \%$, respectively [7].

Several analytical techniques have been used to determine the concentrations of glycosides in S. rebaudiana, including thin layer chromatography (HPTLC) [8]-[10], capillary electrophoresis [11] [12], LC/mass spectrometry [13], electrospray ionization mass spectrometry (ESI-MS) [3], infrared spectroscopy [11] [14], and highperformance liquid chromatography (HPLC) [15]-[20] among others, which vary in sensitivity, precision and accuracy. However, the FAO/WHO Joint Expert Committee on Food Additives (JECFA) in its 73rd meeting has recommended an HPLC method for determination of steviol glycosides [21] and therefore it is the most appropriate to use.

In recent years some varieties of S. rebaudiana, called Criolla (from Paraguay) and Morita II, have been grown in the south of Mexico to determine their adaptation to the weather and soil of the region, with no previous report of major steviol glycosides by JECFA method [21]. It is known that a method must be validated before using routinely and whenever the conditions change (e.g. instrument with different characteristics) [22] therefore in a previous report, the authors demonstrate that it is possible to quantify a minor glycoside such as rebaudioside D [23] using JECFA method (2010) [21]. However, JECFA method (2010) [21] has not been applied to quantification of major glycosides-Rebaudioside A and Stevioside-contained in varieties grown in Mexico and in this regard there is only one previous report [24], but the methodology used is no longer recommended because of the poor reproducibility and long equilibration times of $\mathrm{NH}_{2}$ columns [20]. Therefore, the aim of this study was to determine the content of rebaudioside A and stevioside in the leaves of S. rebaudiana B. cultivated in Mexico by the validated JECFA (2010) HPLC method.

\section{Materials and Methods}

\subsection{Chemical and Reagents}

Standards of rebaudioside A (01432) and stevioside (S3572) were purchased from Sigma-Aldrich (USA) with a purity established by manufactured of $96 \%$ and $98 \%$, respectively; acetonitrile and water (HPLC grade) were purchased from J.T Baker (Phillipsburg, NJ). Glycosides standards were lyophilized under vacuum pressure of $133 \times 10^{-3} \mathrm{Bar}$ and a temperature of $-40^{\circ} \mathrm{C}$ (Labconco, Kansas City, MO), then mixed with HPLC water, filtered trough $0.45 \mu \mathrm{m}$ and stored at $-20^{\circ} \mathrm{C}$ prior to use.

\subsection{HPLC Conditions}

A high-performance liquid chromatography method was performed, according to JECFA (2010) [21] with Agilent 100 HPLC system. Chromatographic method was carried out on Luna C18 (2) (length: $250 \mathrm{~mm}$; inner diameter: $4.6 \mathrm{~mm}$, particle size: $5 \mu \mathrm{m}$ ) column (Phenomenex Co., Ltd., CA, USA) without temperature control with UV-Vis detector set to a wavelength of $210 \mathrm{~nm}$. Mobile phase was a 32:68 (v/v) mixture of acetonitrile and $10 \mathrm{mmol} / \mathrm{L}$ sodium phosphate buffer $(\mathrm{pH} 2.6)$ at a flow rate of $1 \mathrm{~mL} / \mathrm{min}$. The sample injection volume was 20 $\mu \mathrm{L}$ and analysis was performed with Clarity software 2.7.3.498 version (2009). 


\subsection{Stevia rebaudiana Extract}

Two varieties of S. rebaudiana, Criolla and Morita II was grown and collected from the Southeast of México. Five hundred milligrams of dried leaves were extracted three times with $5 \mathrm{~mL}$ of water each time in a boiling water bath for $30 \mathrm{~min}\left(100^{\circ} \mathrm{C}\right)$. Extracts were cooled to room temperature and centrifuged at $2500 \times \mathrm{g}, 10^{\circ} \mathrm{C}$ for 10 minutes. The aqueous phases were transferred to a $25 \mathrm{~mL}$ volumetric flask and filled to capacity. The solution was filtered through a $0.45 \mu \mathrm{m}$ membrane filter before HPLC analysis [20].

\subsection{Validation Parameters}

In order to determine the content of rebaudioside A and stevioside with quality, reliability and consistency, validation parameters were calculated. In agreement with ICH guidelines [25], sensitivity, linearity, limit of detection (LOD), limit of quantification (LOQ), accuracy and precision of each glycosides was calculated. For this purpose, $10 \mathrm{mg}$ of standard was weighted and diluted with $10 \mathrm{~mL}$ HPLC water to prepare a stock solution; the standard curves were prepared by dilution of the stock solution with HPLC water to reach concentration ranges of $100-500 \mu \mathrm{g} / \mathrm{mL}$ for each glycoside. Each concentration was injected a total of six times onto the HPLC equipment.

Validation parameters were defined and operationalized as follows: The sensitivity is the change in response divided by the corresponding change in the stimulus (slope of the calibration function); the linearity is the ability of the method to obtain results, which are directly proportional to the analyte concentration and was obtained by a linear regression calculated by the method of least squares; limit of detection (LOD) is the lowest concentration of a analyte in a sample that can be detected which was determined by the formula: LOD $=3.3$ (Standard Deviation of intercept)/slope (S); limit of quantitation (LOQ) is the lowest concentration of an analyte in a sample that can be quantitatively determined using the formula $\mathrm{LOQ}=10$ (Standard Deviation of intercept)/slope (S); accuracy is the degree of agreement between the value that is accepted as true and the value found expressed as percentage of recovery of fortified samples and calculated by the equation: Recovery (\%) $=\mathrm{S} 1 /(\mathrm{S} 2+$ S3) $\times 100$; where S1 = amount found $(\mu \mathrm{g} / \mathrm{mL})$ in the spiked sample, S2 = amount present originally in the unfortified sample, and S3 $=$ amount $(\mu \mathrm{g} / \mathrm{mL})$ of analyte added to the sample; finally, precision is the closeness of a series of measurements obtained from multiple samples under prescribed conditions and were expressed as relative standard deviation (\%RSD) of repeatability (intra-day) and intermediate (inter-day) precision [25].

\subsection{Statistical Analysis}

Statgraphics was used to evaluate the linearity of the system, whereas intercept in y, slope with their respective confidence intervals were calculated using the GraphPad Prism program version 5.00. Microsoft Office Excel was used for analysis of limit of quantification, limit of detection, accuracy and precision. Student's t-test was performed using Statgraphics considering $\mathrm{p}<0.05$.

\section{Results and Discussion}

After obtaining the values of area under the peak of the five concentrations in triplicate on two separate occasions, a plot of peak area as a function of analyte concentration was developed and the linear regression was calculated by method of least squares (Figure 1 ).

Asseen in Table 1, the parameters of simple linear regression were calculated for both standards of steviol glycosides at concentrations of $100-500 \mu \mathrm{g} / \mathrm{mL}$.

Since the correlation coefficients and the coefficients of determination of the standard curves were greater than 0.99 , it can be concluded that the analytical methodology used was linear over the concentration range studied and therefore the model is suitable for quantifying the content of glycosides. Similar correlation coefficient and the coefficient of determination ( $>0.99)$ were obtained for rebaudioside D [23] using the same method, demonstrating the application of the method to the determination of glycosides in general.

Repeatability was evaluated by analyzing relative standard deviation (RSD) for area under the peak and also for retention time through the run. Percent of RSD of all concentration were $\leq 1.08$ and $\leq 5.24$ for retention time and area, respectively (Table 2). The average retention time for rebaudioside A was 6.95 min., whereas for stevioside was $7.20 \mathrm{~min}$. Intermediate precision was found by repeating the same procedure, although 7 to 30 days later. 
Table 1. Parameters calculated from linear regression model peak area vs. concentration $(\mathrm{y}=$ $\mathrm{a}+\mathrm{b} * \mathrm{x})$ of rebaudioside $\mathrm{A}$ and stevioside.

\begin{tabular}{ccc}
\hline Paremeters & Rebaudioside A & Stevioside \\
\hline Coefficient of correlation $(\mathrm{r})$ & 0.996 & 0.996 \\
Coefficient of determination $\left(\mathrm{R}^{2}\right)$ & 0.993 & 0.994 \\
y-intercept & 12.41 & -30.54 \\
CI of y-intercept ${ }^{\mathrm{a}}$ & -36.72 to 61.55 & -93.88 to 32.80 \\
Slope (sensitivity) & 4.510 & 6.139 \\
CI of slope & 4.263 to 4.659 & 5.949 to 6.331 \\
LOD $(\mu \mathrm{g} / \mathrm{mL})^{\mathrm{b}}$ & 17.54 & 16.62 \\
LOQ $(\mu \mathrm{g} / \mathrm{mL})^{\mathrm{c}}$ & 53.18 & 50.37 \\
\hline
\end{tabular}

${ }^{\mathrm{a} C I}$ : confidence interval at 95\%; bOD: limit of detection [3.3 (Standard deviation of intercept)/slope (S)]; ${ }^{\mathrm{c}} \mathrm{LOQ}$ : limit of quantification [10 (Standard deviation of intercept)/slope (S)].

(a)

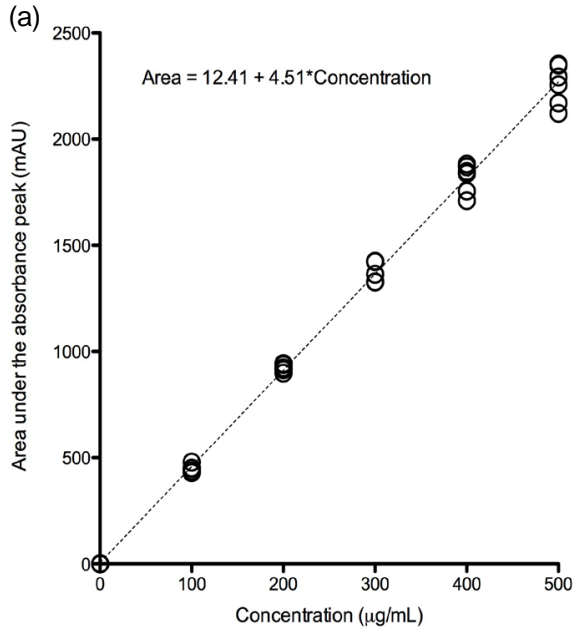

(b)

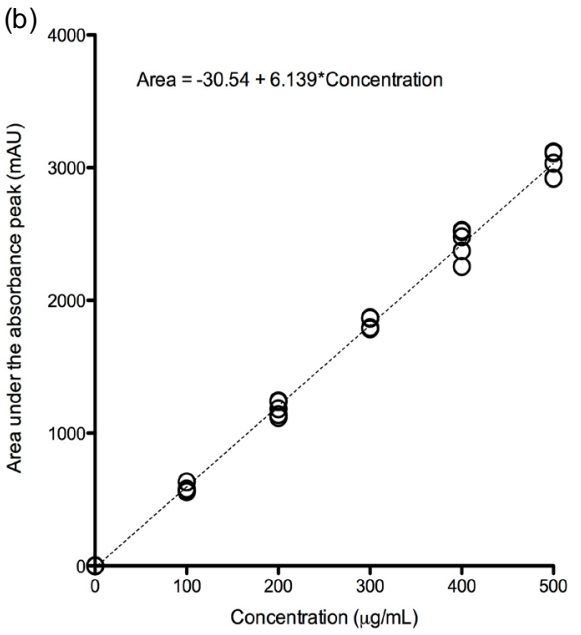

Figure 1. Linearregression of rebaudioside A (a) and stevioside (b) standards curves under chromatographic conditions. Data represents the area under the absorbance peaks for each concentration of rebaudioside A or stevioside (blank circules) and linear regression analysis calculated by the method of least squares (dotted line).

The precision for retention time was $\leq 1.93 \%$ RSD in all cases, while for peak area was $\leq 6.27 \%$ (Table 3 ). In this regard, the \%RSD of peak area found is higher than that reported for rebaudioside A $(0.70 \%)$ or stevioside (0.41\%) using a similar chromatographic method [19], that may be attributed to the purity of the standards (99\%) used by Tada et al. (2011); however given the \%RSD obtained here, the method can be considered precise to quantify both rebaudioside A and stevioside.

After the analysis of sensibility and precision of the method, extracts of S. rebaudiana Bertoni Morita II and Criolla varieties were analyzed to identify rebaudioside A and stevioside present in both. As seen in Figure 2(a), rebaudioside A and stevioside appear in a chromatogram around 6 to 7 minutes and are easily identifiable in the chromatograms of the extracts of Stevia (Figure 2(b) and Figure 2(c)).

Once both glycosides were identified in the chromatogram of the extracts, each sample was analyzed in duplicate and the concentration calculated through the equation of linear regression constructed with the standards. In Morita II variety, the rebaudioside A content $(\mathrm{g} / 100 \mathrm{~g}$ of dry leaf) is significantly higher $(\mathrm{p}<0.001)$ than that found in Criolla variety, whereas for stevioside content is exactly the opposite (Table 4).

As seen in Figure 2(b) and Figure 2(c), in the beginning of the chromatograms there is a matrix load, which may decrease the life of the column and therefore the use of pre-column in the HPLC equipment is strongly 
Table 2. Intra-day precision of rebaudioside A and stevioside.

\begin{tabular}{cccccc}
\hline Precision & $\begin{array}{c}\text { Concentration } \\
(\boldsymbol{\mu g} / \mathbf{m L})\end{array}$ & $\begin{array}{c}\text { Retention time } \\
(\mathbf{m e a n} \pm \mathbf{S D})\end{array}$ & $\begin{array}{c}\text { \%RSD } \\
\text { time }\end{array}$ & $\begin{array}{c}\text { Peak area } \\
\text { (mean } \pm \text { SD) }\end{array}$ & \%RSD area \\
\hline Rebaudioside A & 100 & $6.99 \pm 0.05$ & 0.76 & $541.58 \pm 23.66$ & 5.24 \\
& 300 & $6.97 \pm 0.06$ & 0.93 & $1316.0 \pm 34.43$ & 2.62 \\
Stevioside & 500 & $6.98 \pm 0.08$ & 1.08 & $2215.24 \pm 32.19$ & 1.45 \\
& 100 & $7.17 \pm 0.02$ & 0.34 & $565.63 \pm 13.86$ & 2.45 \\
& 300 & $7.18 \pm 0.04$ & 0.55 & $1621.16 \pm 56.67$ & 3.50 \\
\hline
\end{tabular}

\%RSD: relative standard deviation.

Table 3. Inter-day precision of rebaudioside A and stevioside.

\begin{tabular}{cccccc}
\hline Precision & $\begin{array}{c}\text { Concentration } \\
(\boldsymbol{\mu g} / \mathbf{m L})\end{array}$ & $\begin{array}{c}\text { Retention time } \\
(\text { mean } \pm \text { SD) }\end{array}$ & $\begin{array}{c}\text { \%RSD } \\
\text { time }\end{array}$ & $\begin{array}{c}\text { Peak area } \\
(\text { mean } \pm \text { SD) }\end{array}$ & \%RSD area \\
\hline \multirow{2}{*}{ Rebaudioside A } & 100 & $6.94 \pm 0.10$ & 1.51 & $445.21 \pm 19.31$ & 4.34 \\
& 300 & $6.91 \pm 0.13$ & 1.89 & $1338.36 \pm 17.93$ & 1.34 \\
Stevioside & 500 & $6.92 \pm 0.13$ & 1.93 & $2206.31 \pm 53.04$ & 2.40 \\
& 100 & $7.24 \pm 0.05$ & 0.74 & $584.92 \pm 36.67$ & 6.27 \\
& 300 & $7.25 \pm 0.04$ & 0.52 & $1745.14 \pm 85.62$ & 4.91 \\
\hline
\end{tabular}

\%RSD: relative standard deviation.

Table 4. Major steviol glycosides content in dried leaves of S. rebaudiana Morita II and Criolla (g/100g) grown in the Southeast of Mexico.

\begin{tabular}{ccc}
\hline Glycosides & Morita II (mean \pm S.D.) & Criolla (mean \pm S.D.) \\
\hline Rebaudioside A & $15.15 \pm 0.02^{\mathrm{a}}$ & $4.03 \pm 0.01^{\mathrm{b}}$ \\
Stevioside & $3.97 \pm 0.003^{\mathrm{a}}$ & $8.80 \pm 0.14^{\mathrm{b}}$
\end{tabular}

Values are expressed as mean \pm standard deviation. Different letter in the same row denote significant differences at $\mathrm{p}<0.001$ (Student's t-test).

recommended. In this context it is also possible to use a pre-analytical method such as SPE extraction [20] to remove these impurities. However, although a pre-treatment could be useful to improve the chromatographic profile, it is not essential for the identification and quantification of rebaudioside A and stevioside.

The high content of rebaudioside A found in the variety Morita II is somewhat expected since this variety was bred to be used as a sweetener [5], given the high sweetening power of rebaudioside A and its little bitter aftertaste. Worldwide it has been reported concentrations of rebaudioside A and stevioside as high as $61.2 \%$ [7] and $22 \%$ [4], depending on the variety and growing location. However, in Mexico there are only one previous report of rebaudioside A and stevioside both in Morita II and Criolla varieties [24], although using a different chromatographic technique with an amino bond column. Moguel et al. (2011) reported $9.12 \%$ and $2.42 \%$ of rebaudioside A in Morita and Criolla, respectively; they also reported $2.18 \%$ and 5.09\% of stevioside in Morita and Criolla, respectively. Comparing the higher content of stevioside and rebaudioside A found in this work with those previously reported by Moguel et al. (2011) it is noteworthy that both steviol glycosides in the two varieties the differences are in the same proportion (1.8-fold). Considering that the results are only comparable with what has been reported for $S$. rebaudiana grown in Mexico, this discrepancy could be due to the effect of the growing season or harvest (related to solar radiation and rain precipitation) or the use of a different analytical method. In fact, JECFA method [21] used in this work involves a more stable column compare to amino bonded column [19], lower retention times for rebaudioside A and stevioside, and a lower proportion of acetonitrile in 

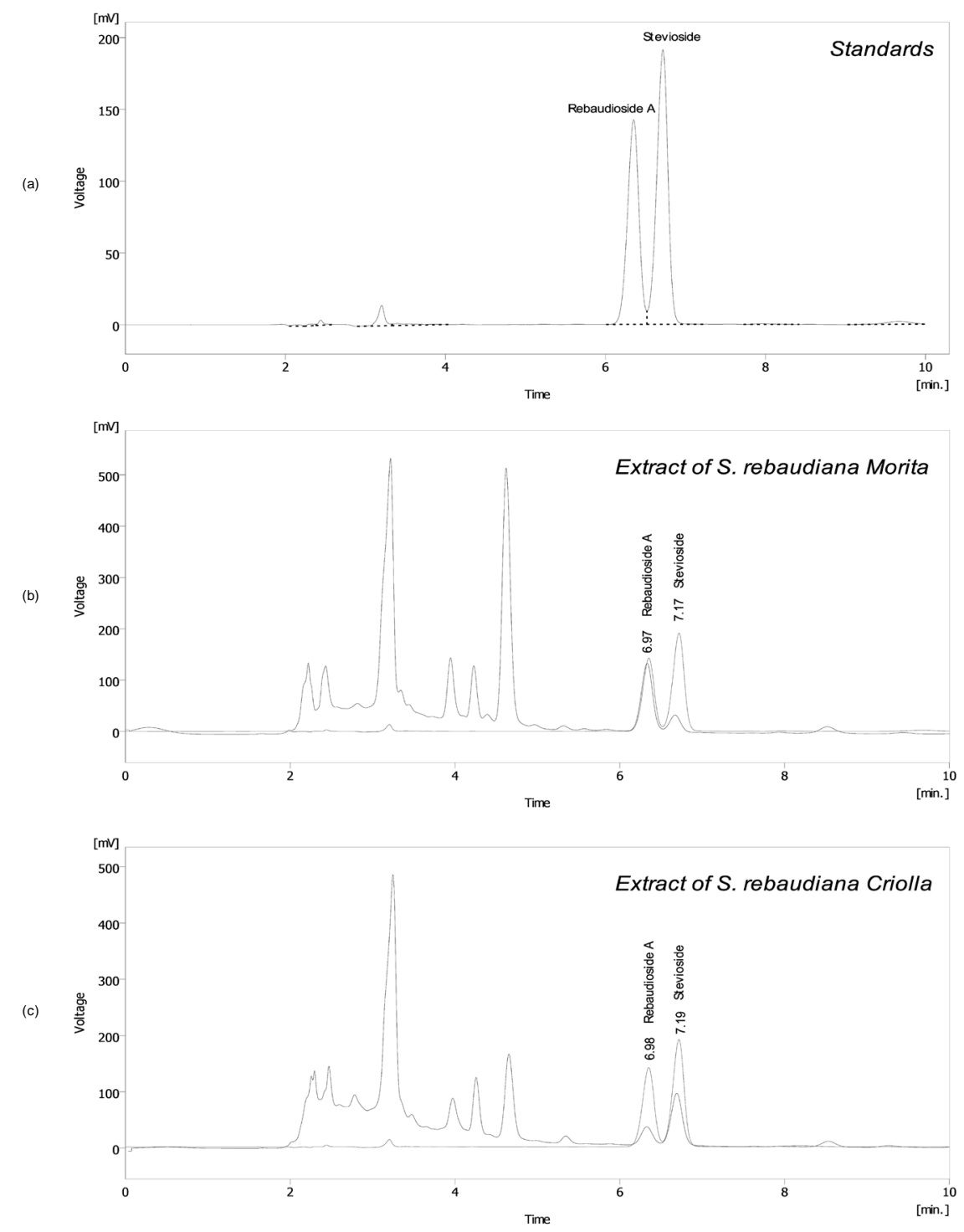

Figure 2. Typical chromatogram of rebaudioside A, stevioside and S. rebaudiana extracts under chromatography conditions. A mixture of rebaudioside A and stevioside was analyzed alone (a) or overlaid with Morita II (b) or Criolla (c) varieties.

the mobile phase than the method described for amino bonded columns. Taking these data together, the content of major glycosides found here are from a validated method, which involves less time and use of moderately toxic substance as it is the acetonitrile.

Finally, accuracy was evaluated by performing recovery studies of fortified samples; One hundred $\mu \mathrm{g} / \mathrm{mL}$ of rebaudioside A or stevioside was added to three samples of $S$. rebaudiana extract previously quantified and analyzed trough the HPLC method. The analysis of spiked samples, conducted in triplicate, demonstrated a good recovery of rebaudioside A of $99.5 \%$ - $92.29 \%$, whereas the recovery of stevioside was in the range of $97.91 \%$ $104.49 \%$ in both varieties of Stevia (Table 5).

The recovery rate found for rebaudioside $\mathrm{A}$ and stevioside are in the range that has been reported previously for rebaudioside A (93\% - 108\%) or stevioside (95.7\% - 106\%) [8] [20] [26] in different chromatographic methods and therefore considered acceptable.

Taking in consideration that using the same HPLC method it is possible to quantify minor glycosides such as rebaudioside D [23] as well as major glycosides, as demonstrated in the present work, its application to multiple samples is feasible at the laboratory. 
Table 5. Accuracy of analytical method expressed as a recovery percentage of spiked samples.

\begin{tabular}{ccc}
\hline \multirow{2}{*}{ Variety } & \multicolumn{2}{c}{ Glycoside (\% of recovery) } \\
\cline { 2 - 3 } S. rebaudiana Criolla & Rebaudioside A & Stevioside \\
S. rebaudiana Morita II & 99.50 & 97.91 \\
& 92.29 & 104.49 \\
\hline
\end{tabular}

\section{Conclusion}

Rebaudioside A and stevioside were determined in Stevia rebaudiana leaves grown in Mexico; rebaudioside A content $(\mathrm{g} / 100 \mathrm{~g})$ in Morita II was $15.15 \pm 0.02$ while stevioside was $3.97 \pm 0.003$; in the case of Criolla they were $4.03 \pm 0.01$ and $8.80 \pm 0.14$, respectively $(\mathrm{p}<0.001)$. This was performed by a validated HPLC method that showed sensitivity of 4.15 and 6.139 , with a LOD of $17.54 \mu \mathrm{g} / \mathrm{mL}$ and $16.62 \mu \mathrm{g} / \mathrm{mL}$, a LOQ of $53.18 \mu \mathrm{g} / \mathrm{mL}$ and $50.37 \mu \mathrm{g} / \mathrm{mL}$, for Rebaudioside A and Stevioside, respectively; the method was accurate (100\% $\pm 10 \%)$, linear $(\mathrm{R}=0.99)$, and precise $(\leq 6.27 \% \mathrm{RSD})$, and therefore it could be routinely applied to quantify these glycosides in $S$. rebaudiana grown elsewhere.

\section{Acknowledgements}

This work was supported by Programa de Mejoramiento al Profesorado-PROMEP-SEP and Fondos FiscalesINIFAP, Also, I.A.G. received a CONACYT's scholarship during postgraduate studies.

\section{References}

[1] Chaturvedula, V.S., Upreti, M. and Prakash, I. (2011) Diterpene Glycosides from Stevia rebaudiana. Molecules, 16, 3552-3562. http://dx.doi.org/10.3390/molecules16053552

[2] Goyal, S.K., Samsher and Goyal, R.K. (2010) Stevia (Stevia rebaudiana) a Bio-Sweetener: A Review. International Journal of Food Sciences and Nutrition, 61, 1-10. http://dx.doi.org/10.3109/09637480903193049

[3] Jackson, A.U., Tata, A., Wu, C., Perry, R.H., Haas, G., West, L. and Cooks, R.G. (2009) Direct Analysis of Stevia Leaves for Diterpene Glycosides by Desorption Electrospray Ionization Mass Spectrometry. Analyst, 134, 867-874. http://dx.doi.org/10.1039/b823511b

[4] Wöelwer-Rieck, U. (2012) The Leaves of Stevia rebaudiana (Bertoni), Their Constituents and the Analyses Thereof: A Review. Journal of Agricultural and Food Chemistry, 60, 886-895. http://dx.doi.org/10.1021/jf2044907

[5] Brandle, J.E. (1999) Genetic Control of Rebaudioside A and C Concentration in Leaves of the Sweet Herb, Stevia rebaudiana. Canadian Journal of Plant Science, 79, 85-92. http://dx.doi.org/10.4141/P98-048

[6] Jarma-Orozco, A., Araméndiz-Tatis, H. and Cleves-Leguízamo, A. (2011) Phenotypic Stability and Plant Densities of Stevia (Stevia rebaudiana Bert.) Genotypes in the Caribbean Region of Colombia. Acta Agronómica, 60, 165-175.

[7] Ohta, M. and Sasa, S. (2010) Characterization of Novel Steviol Glycosides from Leaves of Stevia rebaudiana Morita. Phytochemistry, 57, 199-209. http://dx.doi.org/10.5458/jag.57.199

[8] Chester, K., Tamboli, E., Singh, M. and Ahmad, S. (2012) Simultaneous Quantification of Stevioside and Rebaudioside A in Different Samples Collected from the Indian Subcontinent. Journal of Pharmacy and Bioallied Sciences, 4, 276-281. http://dx.doi.org/10.4103/0975-7406.103236

[9] Jaitak, V., Gupta, A.P., Kaul, V.K. and Ahuja, P.S. (2008) Validated High-Performance Thin-Layer Chromatography Method for Steviol Glycosides in Stevia rebaudiana. Journal of Pharmaceutical and Biomedical Analysis, 47, 790794. http://dx.doi.org/10.1016/j.jpba.2008.03.022

[10] Londhe, S.V. and Nanaware, S.M. (2013) HPTLC Method for Simultaneous Analysis of Stevioside and Rebaudioside-A in Stevia rebaudiana. Journal of AOAC International, 96, 24-26. http://dx.doi.org/10.5740/jaoacint.11-257

[11] Dacome, A., Da Silva, C., Da Costa, C., Fontana, J., Adelmann, J. and Da Costa, S. (2005) Sweet Diterpenic Glycosides Balance of a New Cultivar of Stevia rebaudiana (Bert.) Bertoni: Isolation and Quantitative Distribution by Chromatographic, Spectroscopic, and Electrophoretic Methods. Process Biochemistry, 40, 3587-3594. http://dx.doi.org/10.1016/j.procbio.2005.03.035

[12] Mauri, P., Catalano, G., Gardana, C. and Pietta, P. (1996) Analysis of Stevia Glycosides by Capillary Electrophoresis. Electrophoresis, 17, 367-371. http://dx.doi.org/10.1002/elps.1150170213 
[13] Wang, L.Z., Goh, B.C., Fan, L. and Lee, H.S. (2004) Sensitive High-Performance Liquid Chromatography/Mass Spectrometry Method for Determination of Steviol in Rat Plasma. Rapid Communications in Mass Spectrometry, 18, 83-86. http://dx.doi.org/10.1002/rcm.1285

[14] Hearn, L. and Subedi, P. (2009) Determining Levels of Steviol Glycosides in the Leaves of Stevia rebaudiana by Near Infrared Reflectance Spectroscopy. Journal of Food Composition and Analysis, 22, 165-168. http://dx.doi.org/10.1016/j.jfca.2008.10.008

[15] Bergs, D., Burghoff, B., Joehnck, M., Martin, G. and Schembecker, G. (2012) Fast and Isocratic HPLC-Method for Steviol Glycosides Analysis from Stevia rebaudiana Leaves. Journal für Verbraucherschutz und Lebensmittelsicherheit, 7, 147-154. http://dx.doi.org/10.1007/s00003-012-0760-5

[16] Gardana, C., Scaglianti, M. and Simonetti, P. (2010) Evaluation of Steviol and Its Glycosides in Stevia rebaudiana Leaves and Commercial Sweetener by Ultra-High-Performance Liquid Chromatography-Mass Spectrometry. Journal of Chromatography A, 1217, 1463-1470. http://dx.doi.org/10.1016/j.chroma.2009.12.036

[17] Hashimoto, Y., Moriyasu, M. and Nakamura, S. (1978) High Performance Liquid Chromatographic Determination of Stevia Components on a Hydrophilic Packed Column. Journal of Chromatography A, 161, 403-405. http://dx.doi.org/10.1016/S0021-9673(01)85262-6

[18] Kolb, N., Herrera, J.L., Ferreyra, D.J. and Uliana, R.F. (2001) Analysis of Sweet Diterpene Glycosides from Stevia rebaudiana: Improved HPLC Method. Journal of Agricultural and Food Chemistry, 49, 4358-4341. http://dx.doi.org/10.1021/jf010475p

[19] Tada, A., Ishozuki, K., Iwamura, J., Mikami, H., Hirao, Y., Fujita, I., Yamazaki, T., Akiyama, H. and Kawamura, Y. (2013) Improvement of the Assay Method for Steviol Glycosides in the JECFA Specification. American Journal of Analytical Chemistry, 4, 190-196. http://dx.doi.org/10.4236/ajac.2013.44024

[20] Wöelwer-Rieck, U., Lankes, C., Wawrzun, A. and Wüst, M. (2010) Improved HPLC Method for Evaluation of the Major Steviol Glycosides in Leaves of Stevia rebaudiana. European Food Research and Technology, 231, 581-588. http://dx.doi.org/10.1007/s00217-010-1309-4

[21] JECFA (2010) Steviol Glycosides. FAO Joint Expert Committee on Food Additives (JECFA) Monographs. 17-21

[22] Huber, L. (2007) Validation of Analythical Methods: Validation and Qualification in Analytical Laboratories. 2nd Edition, Informa Healthcare, New York, 125.

[23] Aranda-González, I., Moguel-Ordoñez, Y., Betancur-Ancona, D. (2014) Rapid HPLC Method for Determination of Rebaudioside D in Leaves of Stevia rebaudiana Bertoni Grown in the Southeast of México. American Journal of Analytical Chemistry, 5, 813-819. http://dx.doi.org/10.4236/ajac.2014.513090

[24] Moguel, O., Ruiz, J., Ramírez, J., Avilés, B. and García, A. (2011) Glycosides Content in Leaves of Four Genotypes of Stevia rebaudiana Bertoni in Plantations Established in Quintana Roo, México. VI Reunión Nacional de Innovación Agrícola, León, 268.

[25] ICH (2005) Harmonized Tripartite Guideline Validation on Analytical Procedures: Text and Methodology. International Conference on Harmonization of Technical Requirements for Registration of Pharmaceuticals for Human Use Q2(R1), Geneva.

[26] Jaworska, K., Krynitsky, A.J., Rader, J.I. (2012) Simultaneous Analysis of Steviol and Steviol Glycosides by Liquid Chromatography with Ultraviolet Detection on a Mixed-Mode Column: Application to Stevia Plant Material and Stevia-Containing Dietary Supplements. Journal of AOAC International, 95, 1588-1596. http://dx.doi.org/10.5740/jaoacint.11-435 